medRxiv preprint doi: https://doi.org/10.1101/2021.04.25.21256062; this version posted April 27, 2021. The copyright holder for this preprint (which was not certified by peer review) is the author/funder, who has granted medRxiv a license to display the preprint in perpetuity. It is made available under a CC-BY-NC-ND 4.0 International license .

\title{
A prospective longitudinal study of chronic pulmonary aspergillosis in pulmonary tuberculosis
}

\section{in Indonesia (APICAL)}

Findra Setianingrum ${ }^{1,2,3^{*}}$, Anna Rozaliyani $i^{1,3,4,8^{*}}$, Robiatul Adawiyah ${ }^{1,3}$, Ridhawati Syam ${ }^{1,3}$, Mulyati Tugiran ${ }^{1,3}$, Cut Yulia I. Sari ${ }^{5}$, Finny Nandipinto ${ }^{3}$, Johannes Ramnath ${ }^{6,7}$, Arief Riadi Arifin $^{8,3}$, Diah Handayani ${ }^{3,9}$, Erlina Burhan ${ }^{3,9}$, Martin C. Rumende ${ }^{10,11}$, Retno Wahyuningsih ${ }^{1,3,12}$, Riina Rautemaa-Richardson ${ }^{2,13,14}$, David W. Denning ${ }^{2,13}$

${ }^{1}$ Department of Parasitology, Faculty of Medicine, Universitas Indonesia

${ }^{2}$ Manchester Fungal Infection Group, Faculty of Biology, Medicine and Health, University of Manchester, United Kingdom

${ }^{3}$ Pulmonary Mycosis Centre, Jakarta, Indonesia

${ }^{4}$ Grha Permata Ibu Hospital, Jakarta,Indonesia

${ }^{5}$ Jakarta Islamic Hospital, Cempaka Putih, Jakarta, Indonesia

${ }^{6}$ Department of Internal Medicine, Faculty of Medicine, Universitas Kristen Indonesia

${ }^{7}$ Universitas Kristen Indonesia Hospital, Jakarta,Indonesia

${ }^{8} \mathrm{MH}$ Thamrin Hospital, Jakarta, Indonesia

${ }^{9}$ Department of Pulmonology and Respiratory Medicine, Faculty of Medicine, Universitas Indonesia, Persahabatan National Respiratory Referral Hospital, Jakarta, Indonesia

${ }^{10}$ Department of Internal Medicine, Faculty of Medicine Universitas Indonesia

${ }^{11}$ Dr. Ciptomangunkusomo Hospital, Jakarta, Indonesia

${ }^{12}$ Department of Parasitology, Faculty of Medicine, Universitas Kristen Indonesia

${ }^{13}$ Manchester Academic Health Science Centre, University of Manchester, United Kingdom

${ }^{14}$ National Aspergillosis Centre and the Department of Infectious Diseases, Manchester University NHS Foundation Trust, United Kingdom

* Joint first authors

Correspondence: Professor David W Denning, Manchester Fungal Infection Group, Core Technology Facility, Grafton Street, The University of Manchester, Manchester M13 9PL, UK ddenning@manchester.ac.uk 
medRxiv preprint doi: https://doi.org/10.1101/2021.04.25.21256062; this version posted April 27, 2021. The copyright holder for this preprint (which was not certified by peer review) is the author/funder, who has granted medRxiv a license to display the preprint in perpetuity. It is made available under a CC-BY-NC-ND 4.0 International license .

\begin{abstract}
Objectives: Chronic pulmonary aspergillosis (CPA) can complicate recovery from pulmonary tuberculosis (TB). CPA may also be misdiagnosed as bacteriologically-negative TB. This study aimed to determine the incidence of CPA in patients treated for TB in Indonesia; a country with a high incidence of TB.
\end{abstract}

Methods: In this prospective, longitudinal cohort study in patients treated for pulmonary TB, clinical, radiological and laboratory findings were analysed. Sputum was collected for fungal culture and TB PCR. Patients were assessed at baseline (0-8 weeks) and at the end (5-6 months) of TB therapy. CPA diagnosis was based on symptoms ( $\geq 3$ months), characteristic radiological features and positive Aspergillus serology, and categorized as proven, probable and possible.

Results: Of the 216 patients recruited, 128 (59\%) were followed up until end of TB therapy. At baseline, 91 (42\%) had microbiological evidence for TB. Aspergillus-specific IgG was positive in $64(30 \%)$ patients and went from negative to positive in $16(13 \%)$ patients during TB therapy. The incidence of proven and probable CPA at baseline was $6 \%(n=12)$ and $2 \%(n=5)$ and end of TB therapy $8 \%(n=10)$ and $5 \%(n=7)$, respectively. Six patients ( 2 with confirmed TB) developed an aspergilloma. Diabetes mellitus was a significant risk factor for CPA ( $p=0.040)$. Persistent cough $(n=5,50 \% ; p=0.005)$ and fatigue $(n=6,60 \% ; p=0.001)$ were the most common symptoms in CPA.

Conclusion: CPA should be considered a relatively frequent differential diagnosis in patients with possible or proven TB in Indonesia. Lack of awareness and limited access to Aspergillusspecific IgG tests and CT imaging are obstacles in establishing a CPA diagnosis.

256 words 


\section{Key messages}

What is the key question?

Do what extent is chronic pulmonary aspergillosis (CPA) both a) mistaken for TB and b) co-exists with TB during the course of 6 months therapy

What is the bottom line?

Features consistent with CPA were present in $6 \%$ of patients when starting TB therapy and $8 \%$ at the end of therapy, with some resolving and some developing CPA de novo during TB therapy. At the end of B therapy symptoms, cavitations with Aspergillus-specific IgG detectable were the key features of CPA.

Why read on?

Co-existence of TB and CPA is present in a substantial minority of patients starting and ending TB therapy, and needs addressing in terms of diagnosis, dual therapy and follow up. 
medRxiv preprint doi: https://doi.org/10.1101/2021.04.25.21256062; this version posted April 27, 2021. The copyright holder for this preprint (which was not certified by peer review) is the author/funder, who has granted medRxiv a license to display the preprint in perpetuity. It is made available under a CC-BY-NC-ND 4.0 International license .

\section{Introduction}

The link between pulmonary TB and the subsequent development CPA is well established for those who have recovered from TB [1,2]. Studies to date have addressed the relative rate of development of CPA with slightly different incidence rates depending on the modes of testing, timing, diagnostic criteria used and the patient population [3-5]. No prospective studies have yet addressed the occurrence of both CPA and TB during anti-tuberculous (TB) therapy, although a few such cases are described [6]. Mis-diagnosis of CPA as pulmonary TB is relatively common in clinical practice, but hard to quantify as it is difficult to absolutely rule TB out as a diagnosis [5]. No prospective studies of CPA have been done in Indonesia. In 2019, Indonesia reported 845,000 TB cases to the WHO, $87 \%$ pulmonary [7] so the numerical impact of misdiagnosis could be large.

Once a diagnosis of pulmonary tuberculosis is considered based on clinical symptoms, disease duration and radiological appearance, the standard approach and general clinical recommendation is to commence anti-TB therapy. In a review of older studies before the HIV era and before effective therapy for pulmonary TB was available [8], Tiemersma found that even in those with smear positive TB, the spontaneous recovery was 30\% (14-47\%) and in those with smear negative TB was $\sim 80 \%$. So the drive to immediately treat patients with suspected TB is driven by concern for transmissibility, rather than immediate death of the patient. In the era of co-infection of HIV and TB, the 1 year mortality is still excessively high, but this is not the predominant problem in Indonesia [9].

This longitudinal study was designed to address the timing of the development of CPA during the course of treated tuberculosis. A very common feature of TB is pulmonary cavitation, and we know that this is an important precursor to CPA $[2,10]$, and given that a) Aspergillus inhalation is inevitable and daily and b) that some genetic variants of humans are strongly associated with CPA, it would seem likely that some patients might develop CPA early in the course of TB $[11,12]$. This early Aspergillus infection could be progressive, or it could be selflimited in those with adequate immune defenses, and in both cases be marked by a raised Aspergillus antibody. This is not currently known [13-15]. 
medRxiv preprint doi: https://doi.org/10.1101/2021.04.25.21256062; this version posted April 27, 2021. The copyright holder for this preprint (which was not certified by peer review) is the author/funder, who has granted medRxiv a license to display the preprint in perpetuity. It is made available under a CC-BY-NC-ND 4.0 International license .

Furthermore, in those with a clinical presentation of TB, it may be that some patients do not have TB, but an alternative diagnosis. The differential diagnosis includes CPA, nontuberculous mycobacterial infection, chronic cavitary pulmonary histoplasmosis, coccidioidomycosis or paracoccidioidomycosis, pulmonary cryptococcal infection, necrotizing lung cancer, pulmonary hydatid disease, actinomycosis, or a sub-acute bacterial infection on a background of bullous emphysema which appears radiologically similar to TB [16-19]. Histoplasmosis is endemic in Indonesia, but coccidioidomycosis and paracoccidioidomycosis are not, so only international travel would allow these infections to be manifest [20]. We hypothesized that some smear and TB PCR negative patients might have CPA and not TB, as described in Nigeria by Oladele [5]. By excluding patients with those previously treated for TB (based on the medical records and verbal confirmation from patients), we have taken out of consideration other populations of patients who might have CPA or a broader differential diagnosis.

Our primary objective was to determine the incidence of CPA during the course of and at the end TB therapy, and to assess if the criteria for CPA diagnosis are suitable for this population of patients who are already ill with TB. A second objective was to assess how many patients who are thought to have TB, but lack microbiological evidence for this, actually have CPA and how many have dual infections. We also hoped to determine if any patients had 'self-resolving CPA', or 'sub-clinical CPA' which does not progress, entities not yet adequately described in the literature, and which challenge the current general concept of CPA as a progressive disorder [21]. Our hypotheses are that: CPA is common and under-diagnosed in TB patients in Indonesia, there is dual infection between CPA and TB, CPA starts to develop during active infection of TB, and the current diagnostic criteria for resource-constrained settings are applicable in Indonesia.

\section{Methods}

\section{Study population}

This was a prospective longitudinal study Patients were enrolled at two tertiary care hospitals (National Referral Centre Persahabatan Hospital and National Referral Centre Cipto 
medRxiv preprint doi: https://doi.org/10.1101/2021.04.25.21256062; this version posted April 27, 2021. The copyright holder for this preprint (which was not certified by peer review) is the author/funder, who has granted medRxiv a license to display the preprint in perpetuity. It is made available under a CC-BY-NC-ND 4.0 International license .

Mangunkusumo Hospital), and 4 district hospitals (Grha Permata Ibu Hospital, Universitas Kristen Indonesia Hospital, Cempaka Putih Jakarta Islamic Hospital, and MH Thamrin Hospital), serving greater Jakarta (12 million). Patients were referred from primary care because of diagnostic uncertainty, patient request or co-morbidity.

All consecutive consenting newly diagnosed pulmonary TB patients were recruited into the study. The exclusion criteria were previous history of TB, multi drug-resistant TB, less than 16 years of age, and non-consenting patients. Ethical approval was obtained from the University Research Ethics Committee, University of Manchester (approval number 16416) and from the ethics committee of the Faculty of Medicine, Universitas Indonesia (approval number 672/UN2.F1/ETIK/2016).

Pulmonary tuberculosis was diagnosed by the attending clinical team based on typical symptoms, positive TB PCR by GeneXpert MTB/RIF (Cepheid, CA, USA) and/or acid fast bacilli (AFB) smear and/or radiology finding positive for TB, as per national guidelines [22]. Culture for Mycobacterium spp. was not done, except in exceptional circumstances. Many patients were treated empirically if the suspicion for pulmonary TB was high.

\section{Data collection}

Patients were assessed at the start of TB therapy (baseline, 0-8 weeks) and at the end of TB therapy (at 5-6 months). The main variables, collected at both time points, were serum Aspergillus-specific IgG levels, symptoms and quality of life scores.

A validated quality of life instrument used in respiratory disease - the St Georges Respiratory Questionnaire (SGRQ) was used in addition to CPA-specific questions [23-25]. This questionnaire consists of 3 domains (activity, impact and symptoms, each with range of 1-100) and high scores reflect worse quality of life.

\section{Sample collection and processing}

Blood samples (5-10ml) and sputum (if produced) was collected from patients in the clinic at both time points. Aspergillus-specific IgG level was measured using the Immulite 2000 system 
medRxiv preprint doi: https://doi.org/10.1101/2021.04.25.21256062; this version posted April 27, 2021. The copyright holder for this preprint (which was not certified by peer review) is the author/funder, who has granted medRxiv a license to display the preprint in perpetuity. It is made available under a CC-BY-NC-ND 4.0 International license .

(Siemens, Berlin, Germany) according to the manufacturer's instructions using a cutoff of 11.5 $\mathrm{mg} / \mathrm{l}$ [26]. Prior to testing, serum was stored in $-80^{\circ} \mathrm{C}$. Sputum from patients with productive cough was tested for TB using GeneXpert MTB/RIF PCR (Cepheid, CA, USA). Acid fast bacilli (AFB) smear results were collected from patients' medical records. Any remaining sputum was cultured for fungi.

\section{Radiological interpretation}

All patients had a chest radiograph at baseline and end of TB therapy. CT scans were also done for patients who could afford them. All images were digitized and reviewed by an experienced radiologist (FN) who coded the appearances systematically and provided a narrative report. All radiographs were also reviewed one of the authors (DWD) who specializes in aspergillosis. All radiographs were interpreted in the absence of data on symptoms or any laboratory findings or the interpretation of the other reviewer. The presence of pleural thickening adjacent to a cavity was required to suspect CPA, as opposed to anywhere on the radiograph - the only finding where there was some difference between the two reviewers who were in agreement for all other criteria.

\section{Definitions}

Proven CPA was diagnosed based on three criteria: 1) at least one of the following symptoms; cough, haemoptysis, chest pain, dyspnea, fatigue, and/or weight loss $\geq 3$ months, AND 2) radiological features indicative of CPA (cavitation, fungal ball or pleural thickening) and/or progressive cavitation on serial chest radiographs AND 3) positive Aspergillus IgG and/or Aspergillus spp detected by culture. The diagnosis of probable CPA was made when criteria 1 and 2 but not 3 were met AND 4) the PCR for M. tuberculosis was negative. Possible CPA was diagnosed in those who met criteria 1 and 2 but not 3 or 4 . Criteria for proven, probable and possible CPA were modified versions from Denning et al [15]. "CPA" in the tables and text refers to proven CPA, unless otherwise stated. 
medRxiv preprint doi: https://doi.org/10.1101/2021.04.25.21256062; this version posted April 27, 2021. The copyright holder for this preprint (which was not certified by peer review) is the author/funder, who has granted medRxiv a license to display the preprint in perpetuity. It is made available under a CC-BY-NC-ND 4.0 International license .

\section{Data analysis}

Statistical analysis was performed with the use of IBM SPSS 25 statistic software. A $p$ value $<0.05$ was considered statistically significant. Data were presented using frequencies and percentages for binary and categorical variables, medians and range for non-normally distributed, continuous variables. The difference between non-parametric continuous variables was analysed using Mann-Whitney U-test for CPA and non CPA groups. Fisher's exact tests or chi-squared tests were used for categorical variables for CPA and non CPA groups. Comparisons of median results across different time points were assessed by Wilcoxon signed-rank test. In addition, post hoc analyses were carried out with McNemar's test with adjusted Bonferonni corrections between a two time-point comparisons.

\section{Results}

A total of 216 patients with pulmonary TB were recruited at the start of their TB therapy and 128 (59\%) patients re-attended the end of TB therapy follow-up appointment (Figure 1). The recruitment phase for the baseline appointments is from February 2017 until April 2018. At baseline, 91 (42\%) of 216 patients had microbiological evidence for TB (positive TB PCR and/or AFB smear), 91 (42\%) patients were clinically diagnosed as TB but had no microbiological evidence of it (negative TB PCR and/or AFB), and 34 (16\%) patients were clinically diagnosed as TB but microbiological diagnostics had not been performed. An additional 2 patients had a positive TB PCR result at the end of TB therapy. Twelve (6\%) patients met the criteria of proven CPA, five (2\%) patients as probable CPA, and $15(7 \%)$ patients as possible CPA, an incidence of $7.9 \%(95 \% \mathrm{Cl}: 4.7,12.3)$ or $14.4 \%$ if possible cases are included. Six patients grew Aspergillus in sputum culture, two of whom met the criteria of possible CPA. None of the patients with proven CPA grew Aspergillus in their sputum.

Males outnumbered females in CPA cases with a 3:1 ratio (Table 1). Diabetes mellitus appeared to be a significant risk factor for CPA at baseline assessment $(p=0.040, R R=3.346,42 \%$ in CPA patients vs $16 \%$ in non-CPA patients). There was significant difference in the proportion of cough (93\% in CPA patients vs $13 \%$ in non-CPA patients), fatigue ( $42 \%$ in CPA patients vs $8 \%$ in 
medRxiv preprint doi: https://doi.org/10.1101/2021.04.25.21256062; this version posted April 27, 2021. The copyright holder for this preprint (which was not certified by peer review) is the author/funder, who has granted medRxiv a license to display the preprint in perpetuity. It is made available under a CC-BY-NC-ND 4.0 International license.

non-CPA patients), and weight-loss (17\% in CPA patients vs $1 \%$ in non-CPA patients) between CPA and non-CPA cases ( $p<0.05)$. Baseline quality of life SGRQ scores are shown in Table 2. There was a significant difference between CPA and non-CPA patients in SQRQ in the symptoms domain [p=0.029, median 58 (CPA) vs 39 (non-CPA)]. Infiltrates (58\% in CPA patients vs $87 \%$ in non-CPA patients), cavitation (92\% in CPA patients vs 52\% in non-CPA patients), air fluid level in cavities (50\% in CPA patients vs $22 \%$ in non-CPA patients) and pleural thickening (84\% in CPA patients vs $27 \%$ in non-CPA patients); all were more common in CPA cases ( $<<0.05)$ (Table 1 ).

The overall prevalence of Aspergillus-specific IgG positivity was 30\% (64/216) at baseline. All $(n=12)$ patients from the CPA group had positive levels of Aspergillus-specific IgG. In the nonCPA group, 52 (26\%) patients showed positive Aspergillus-specific IgG. There was a statistical significance between positive Aspergillus-specific IgG across CPA and non-CPA groups [p <0.001, median 15.4 (CPA) vs 8.3 (non-CPA)] (Table 2).

Nine (4\%) patients died before their end of TB therapy appointment. Eight of them (90\%) had extensive infiltrates and/or cavitation in both lungs. Immulite Aspergillus-specific IgG level was positive in four (44\%) of these patients. Chronic kidney diseases ( $n=3,33 \%)$ and diabetes mellitus $(n=1,11 \%)$ were linked to mortality. One possible CPA patient with multicavitary TB disease died with no other underlying disease. There were no deaths in proven and probable CPA patients.

At the end of TB therapy, those assessed $(n=128)$ had a similar spectrum and frequency of symptoms with the exception of fatigue (60\% vs $13 \%, p=0.001)$ and cough $(50 \%$ vs $11 \%$, p=0.005) which were more common in CPA (Table 3). The overall prevalence of Aspergillusspecific IgG positivity was 52\% (66/128). Ten of 128 patients had CPA, an incidence of $7.8 \%$ (95\%Cl: 7.9, 20.4). All ( $n=10)$ patients from the CPA group had positive levels of Aspergillusspecific IgG. In the non-CPA group, 45 (42\%) patients showed positive Aspergillus-specific IgG. Immulite Aspergillus-specific IgG level increased in CPA patients compared to non-CPA patients [p<0.001, median 24.2 (CPA) vs 9 (non-CPA)]. Quality of life scores dropped dramatically during TB therapy, reflecting improved well being, from a median of 35.9 to 4.8 for overall score $(p<0.001)$ (Table 4). However, this drop was smaller in those with proven CPA (62\% decrease in SGRQ total score) than in those without CPA ( $91 \%$ decrease in SGRQ total score). Radiological 
medRxiv preprint doi: https://doi.org/10.1101/2021.04.25.21256062; this version posted April 27, 2021. The copyright holder for this preprint (which was not certified by peer review) is the author/funder, who has granted medRxiv a license to display the preprint in perpetuity.

findings improved during TB therapy with the exception of pleural thickening, and the interval development of one aspergilloma (Table 3). There was also a slight increase in bronchiectasis (on plain radiography).

Of the 12 patients with features of CPA at baseline, seven (58\%) were categorised as non-CPA cases at the end of TB therapy without any antifungal therapy or surgery. This was mainly due to decrease in symptoms and in infiltrates seen in chest x-rays (Figure 2). Two (17\%) were lost to follow-up and not assessed. The remaining three patients continued to have CPA features at the end of TB therapy. An additional seven patients developed CPA during their TB therapy, resulting in a total of ten (8\%) CPA cases at the end of TB therapy. The risk for developing CPA during TB therapy appears to increase with age [p=0.004, mean 52 (CPA) vs 37.1 (non-CPA)] Table 3.

Of five probable CPA cases at baseline, two improved clinically (resolution of symptoms) and one patient became a possible CPA with decreased persistent symptoms but stable pleural thickening by the end TB therapy. Two patients were lost to follow-up. Of 15 possible CPA at the baseline, one patient improved clinically, another met the criteria for probable CPA and three patients did not have features of CPA cases at the end of TB therapy assessment; 10 patients were lost to follow-up. At the end of TB therapy, probable CPA and possible CPA were detected in seven (5\%) patients and four (3\%) patients, respectively. The clinical and radiology profile of patients at both time-points are compared in Table 3 and 4.

\section{Discussion}

The incidence of proven and probable CPA was $7.9 \%(95 \% \mathrm{Cl}: 4.7,12.3)$ at baseline to $13.3 \%$ $(95 \% \mathrm{Cl}: 7.9,20.4)$ at the end of TB therapy, although the latter figure is marred by substantial loss of follow up, including some deaths, probably of CPA, between these 2 time points. There are three confounding factors that need to be considered when interpreting this finding. First, different patients met the criteria for CPA diagnoses at baseline and end of TB therapy. Second, a notable number of patients were lost in follow-up. Third, the accuracy of the CPA diagnosis is a challenge with 5 probable and 15 possible CPA patients at baseline and 7 probable and 4 
medRxiv preprint doi: https://doi.org/10.1101/2021.04.25.21256062; this version posted April 27, 2021. The copyright holder for this preprint (which was not certified by peer review) is the author/funder, who has granted medRxiv a license to display the preprint in perpetuity. It is made available under a CC-BY-NC-ND 4.0 International license .

possible at the end of TB therapy. Furthermore, some patients had aspergillomas visible on their chest radiograph without clinical or serological features of CPA; 5 at baseline and 1 at the end of TB therapy. If all these patients are assumed to have CPA (which is unlikely for the possible group), the incidence of CPA was $17 \%$ both at baseline and at the end of TB therapy. Nevertheless, it is likely that the true prevalence of CPA during the course of treatment of TB is somewhere between $6 \%$ and $17 \%$ at baseline and $8 \%$ and $17 \%$ at the end of therapy, in Indonesia. These are the first estimates of CPA incidence during anti-TB therapy, made globally.

One of the study objectives was to determine how many patients have dual infections. Coinfection of active pulmonary TB and CPA is reported in previous studies [6,27-29]. Our data indicates more frequent dual infection than previously thought. However, many of these patients appear to resolve their Aspergillus infection and had 'self-resolving CPA'. Several other patients failed to attend the second assessment, so their fate is uncertain. The cause of death in those lost to follow up in our study was uncertain, including determining whether any dual infection patients died before assessment. In Japan, the term chronic progressive pulmonary aspergillosis was coined to separate those who deteriorated from those who remained clinically and radiological stable [21]. We have clear cut evidence of this divergence of disease behaviour in this study.

Male sex was an independent risk factor for CPA in this study. Earlier studies also showed male predominance in CPA compared to Aspergillus colonisation in Japan [30], and in a large CPA cohort in Manchester [25]. It can be speculated that this is due to higher prevalence of other risk factors such as smoking, but supportive data are lacking.

Prior studies have demonstrated the rate of CPA in post-TB therapy populations varies between 4.9\%-14.3\% [2,10]. In Nigeria the CPA rate was reported to be $8.7 \%$ at the end of TB-therapy [5] and in Uganda, 9\% of HIV-infected patients had Aspergillus-specific IgG detectable at the end of TB-therapy [31]. A cross sectional study from Iran reported $13.7 \%$ of 124 HIV-negative TB patients developed CPA (76\% patients were on active TB treatment) [4]. All of these CPA rates are within the ranges of our study. However, these studies provide no or minimal information about the status of the patients at baseline and reflect pooled patient populations assessed at varied time points after TB therapy $[2,10]$. 
medRxiv preprint doi: https://doi.org/10.1101/2021.04.25.21256062; this version posted April 27, 2021. The copyright holder for this preprint (which was not certified by peer review) is the author/funder, who has granted medRxiv a license to display the preprint in perpetuity. It is made available under a CC-BY-NC-ND 4.0 International license.

One element of the diagnosis of CPA is symptoms for $\geq 3$ months (weight loss and/or cough and/or haemoptysis) [15]. But as can be seen, this definition is challenged by our data. TB gives rise to weight loss and cough and many patients have some degree of haemoptysis. We found the relative frequency for CPA and TB to be: cough $93 \%$ vs $13 \%$, fatigue $42 \%$ vs $8 \%$ and weightloss $17 \%$ vs $1 \%$ respectively (Table 1 ). Three months of cough is more discriminatory than any cough. Fatigue has been studied and a score devised for COPD patients applied to CPA patients appears to be useful, but has yet to be translated into routine clinical practice [32]. Chest pain appeared to be a useful discriminator in Nigeria but was only present in 25\% of CPA patients [5]. Three months of haemoptysis was found in only $8 \%$ of patients with CPA, compared to $1 \%$ with TB, but shorter periods of haemoptysis were common and not very discriminatory (Table 1).

In addition to specific symptoms, the SGRQ quality of life score was recorded at baseline. Unremarkably for patients with tuberculosis, scores were moderately high (Table 2), but not at all discriminatory between those with only TB and those with CPA and TB, at baseline. However at 4-6 months after starting anti-tuberculous therapy, those with CPA had persistently raised SGRQ scores in all domains, and there was almost complete resolution of all symptoms in those without (Table 4). Therefore this score might be very useful in Indonesia for identifying CPA at the end of anti-TB therapy. It is worth noting that the SGRQ scores in this study are remarkably low compared with other patients who have recovered from TB in the USA [33], but not Papua, Indonesia [34].

The radiological appearances of CPA and TB partially overlap, with upper lobe predominance and cavitation. While TB does not usually cause pleural thickening in the apices, consolidation can occur which can appear like pleural thickening. Likewise peri-cavitary infiltrates are very typical of CPA, but local consolidation can mimic these findings too. The first description of an aspergilloma by Deve in 1938 described a huge cavity with a fungal ball, which is un-mistakable, but more subtle findings are now understood to be typical of CPA [35]. The typical appearance of a fungal ball or aspergilloma includes the air crescent or air meniscus sign, first described in the context of pulmonary hydatid disease [36,37]. Our study lacks confirmation from CT of the findings seen on chest radiographs in $97.7 \%$ of patients. This is a clear cut study weakness and 
medRxiv preprint doi: https://doi.org/10.1101/2021.04.25.21256062; this version posted April 27, 2021. The copyright holder for this preprint (which was not certified by peer review) is the author/funder, who has granted medRxiv a license to display the preprint in perpetuity. It is made available under a CC-BY-NC-ND 4.0 International license .

arises primarily from a lack of funds to afford CT scanning for most patients and an inability to identify in real time those whose disease required better anatomical definition with CT, as serology was done in batches months after the patients were seen.

There is intrinsic uncertainty in the interpretation of chest radiographs. Concordance between readers is far from $100 \%$, both in ascertaining cavitation in TB (50-70\%) and in aspergillosis $[38,39]$. Our radiographs were read by an experienced radiologist in Indonesia (where the only aspergillosis radiological diagnosis made currently is an aspergilloma) with confirmation by a highly experienced clinician focussed on pulmonary aspergillosis. Separating CPA from TB with a chest radiograph alone with any certainty is not possible.

Partly using this dataset (end of TB therapy only), and a separate cross-sectional study population ( $n=71)$ and both normal and disease controls $(n=190)$, we derived the optimum cutoff for Aspergillus-specific IgG (11.5mg/L) in Indonesia for the Immulite assay [26]. The antibody titres varied substantially between both time points, indicative of a complex interaction between Aspergillus and the immune system during the months of anti-TB therapy.

The presence of an aspergilloma is highly indicative of CPA, with echinococcus and necrotizing lung tumours really the only differential diagnoses. An aspergilloma may represent a single aspergilloma, without symptoms or be a feature of chronic cavitary pulmonary aspergillosis. In this study, aspergillomas were detected in 11 patients, with $8(72.7 \%)$ patients having positive PCR TB and/or AFB smears at baseline, indicating co-infection of Aspergillus in active TB patients. Five (45.5\%) patients had positive Aspergillus-specific IgG by Immulite, four (36.4\%) patients in the end and/or post TB therapy and one (9.1\%) patient showed persistent positive Aspergillus-specific IgG by Immulite but with no accompanying symptoms. Two patients had CT scan-confirmed aspergilloma, both with bacteriogically confirmed TB.

In most patients with aspergillomas, Aspergillus IgG was negative when first seen and most were therefore classified as non-CPA. Seroconversion of Immulite from negative to positive Aspergillus-specific IgG occurred in all 5 patients with persistent aspergilloma. Aspergillomas with negative Aspergillus fumigatus IgG antibody has been observed in Africa and may relate to non-fumigatus infections or a muted antibody response $[2,5]$. 
medRxiv preprint doi: https://doi.org/10.1101/2021.04.25.21256062; this version posted April 27, 2021. The copyright holder for this preprint (which was not certified by peer review) is the author/funder, who has granted medRxiv a license to display the preprint in perpetuity. It is made available under a CC-BY-NC-ND 4.0 International license .

The other study objective was to determine how many patients are mis-diagnosed as TB when in fact they have CPA. Ruling out TB can be difficult, so complete confidence in this assertion for individual patients is usually difficult. Community-acquired Aspergillus community acquired pneumonia without any evidence of immunocompromised can occur $[40,41]$, often following significant environmental exposures such as bark chippings, compost and gardening [42,43]. Some of these patients fail to complete resolve their Aspergillus infection, and do not die developing CPA. It is highly likely that some of the clinically diagnosed cases of TB in this study with positive Aspergillus IgG had community-acquired Aspergillus CAP and some went on to develop CPA.

We therefore propose that CPA should be included as an alternative diagnosis of pulmonary TB, especially if there is no clinical and radiological improvement after starting TB therapy. Pulmonary TB and CPA may co-exist and both diseases require their own management plan. In the context of non-tuberculous mycobacterial infection and CPA, the outcomes of those with dual infections were much worse (11.5-fold increased mortality) [19], this has yet to be ascertained for those with TB. The availability of Aspergillus antibody testing and CT scanning are important components of optimal CPA diagnosis. The study is important for the future study of CPA in Indonesia. CPA as an alternative or co-existing disease in TB patients in Indonesia is important for clinicians and to galvanise social and political will of multiple stakeholders to support improvement of diagnostic capacity of fungal disease in Indonesia.

\section{Acknowledgement}

We would like to thank all the staffs at the Department of Parasitology Faculty of Medicine University of Indonesia for their help in sample storage and testing of sputum samples. We gratefully acknowledge Dr. John Belcher of the department of medical statistics for statistical support. We would also like to acknowledge support from the staffs at the Mycology Reference Centre Manchester for providing training of manual Aspergillus-specific IgG ELISA tests and support throughout the project.

\section{Contributors}

$\mathrm{FS}, \mathrm{AR}, \mathrm{EB}$ and RW contributed to the conception and design, acquisition of the data, and analyses and interpretation of the data. RA, RS, MT, CYIS, FN, JR, ARA, DH, and MCR contributed to acquisition of the data, and analyses and interpretation of the data. RR and DWD contributed to the conception and design, analyses and interpretation of the data. All authors made a 
medRxiv preprint doi: https://doi.org/10.1101/2021.04.25.21256062; this version posted April 27, 2021. The copyright holder for this preprint (which was not certified by peer review) is the author/funder, who has granted medRxiv a license to display the preprint in perpetuity. It is made available under a CC-BY-NC-ND 4.0 International license .

significant intellectual contribution to the drafting of the work and contributed to the approval of the final version of the manuscript.

\section{Funding}

The scholarship to support the studies of the first author was provided by Lembaga Pengelola Dana Pendidikan (20160222045506), Republik Indonesia. Prof D Denning is partly supported by the NIHR Manchester Biomedical Research Centre.

\section{Competing Interests}

None declared.

\section{References}

1. Denning, D.W.; Pleuvry, A.; Cole, D.C. Global Burden of Chronic Pulmonary Aspergillosis as a Sequel to Pulmonary Tuberculosis. Bull. World Health Organ., 2011, 89, 864-872.

2. Page, I.D.; Byanyima, R.; Hosmane, S.; Onyachi, N.; Opira, C.; Richardson, M.; Sawyer, R.; Sharman, A.; Denning, D.W. Chronic Pulmonary Aspergillosis Commonly Complicates Treated Pulmonary Tuberculosis with Residual Cavitation. Eur. Respir. J., 2019, 53, 1-13.

3. Rodríguez, N.B.; Juan-Galán, J.L.S.; Andreu, C.M.F.; Yera, D.M.; Pita, M.B.; Lancha, M.R.P.; Martínez, R.E.V.; Zaragozí, M.T.I.; Machín, G.F.M. Chronic Pulmonary Aspergillosis in Patients with Underlying Respiratory Disorders in Cuba-A Pilot Study. J. Fungi, 2019, 5, 4-11.

4. Hedayati, M.T.; Azimi, Y.; Droudinia, A.; Mousavi, B.; Khalilian, A.; Hedayati, N.; Denning, D.W. Prevalence of Chronic Pulmonary Aspergillosis in Patients with Tuberculosis from Iran. Eur. J. Clin. Microbiol. Infect. Dis., 2015, 34, 1759-1765.

5. Oladele, R.O.; Irurhe, N.K.; Foden, P.; Akanmu, A.S.; Gbaja-Biamila, T.; Nwosu, A.; Ekundayo, H.A.; Ogunsola, F.T.; Richardson, M.D.; Denning, D.W. Chronic Pulmonary Aspergillosis as a Cause of Smear-Negative TB and/or TB Treatment Failure in Nigerians. Int. J. Tuberc. Lung Dis., 2017, 21, 1056-1061.

6. Bekele, A.; Ali, A.; Biluts, H. Surgically Treated Pulmonary Tuberculosis: Report on Cases from Tikur Anbess Hospital, Addis Ababa, Ethiopia. Ethiop Med J, 2008, 46, 261-266.

7. WHO. Tuberculosis Profile (Indonesia) in Estimates of TB and MDR-TB Burden; 2019.

8. Tiemersma, E.W.; van der Werf, M.J.; Borgdorff, M.W.; Williams, B.G.; Nagelkerke, N.J.D. Natural History of Tuberculosis: Duration and Fatality of Untreated Pulmonary Tuberculosis in HIV Negative Patients: A Systematic Review. PLoS One, 2011, 6.

9. Trinh, Q.M.; Nguyen, H.L.; Nguyen, V.N.; Nguyen, T.V.A. International Journal of Infectious Diseases Tuberculosis and HIV Co-Infection - Focus on the Asia-Pacific Region. Int. J. Infect. Dis. , 2015, 32, 170-178.

10. The Research Committee of The British Tubrculosis Association. Aspergillus in Persistent 
medRxiv preprint doi: https://doi.org/10.1101/2021.04.25.21256062; this version posted April 27, 2021. The copyright holder for this preprint

(which was not certified by peer review) is the author/funder, who has granted medRxiv a license to display the preprint in perpetuity. It is made available under a CC-BY-NC-ND 4.0 International license .

Lung Cavities after Tuberculosis. Tubercle, 1968, 49, 1-10.

11. Smith, N.L.D.; Hankinson, J.; Simpson, A.; Denning, D.W.; Bowyer, P. Reduced Expression of TLR3, TLR10 and TREM1 by Human Macrophages in Chronic Cavitary Pulmonary Aspergillosis, and Novel Associations of VEGFA, DENND1B and PLAT. Clin. Microbiol. Infect., 2014, 20, 0960-0968.

12. Kwon-Chung, K.J.; Sugui, J.A. Aspergillus Fumigatus-What Makes the Species a Ubiquitous Human Fungal Pathogen? PLoS Pathog., 2013, 9, 1-4.

13. Chakaya, J.; Kirenga, B.; Getahun, H. Long Term Complications after Completion of Pulmonary Tuberculosis Treatment: A Quest for a Public Health Approach. J. Clin. Tuberc. Other Mycobact. Dis., 2016, i, 10-12.

14. Godet, C.; Alastruey-Izquierdo, A.; Flick, H.; Hennequin, C.; Mikilps-Mikgelbs, R.; Munteanu, O.; Page, I.; Seidel, D.; Salzer, H.J.F. A CPAnet Consensus Statement on Research Priorities for Chronic Pulmonary Aspergillosis: A Neglected Fungal Infection That Requires Attention. J. Antimicrob. Chemother., 2017, 73, 1-7.

15. Denning, D.W.; Page, I.; Chakaya, J.; Jabeen, K.; Jude, C.M.; Cornet, M.; AlastrueyIzquierdo, A.; Bongomin, F.; Bowyer, P.; Chakrabarti, A.; Gago, S.; Guto, J.; Hochhegger, B.; Hoenigl, M.; Irfan, M.; Irurhe, N.; Izumikawa, K.; Kirenga, B.; Manduku, V.; Moazam, S.; Oladele, R.; Richardson, M.D.; Tudela, J.L.R.; Rozaliyani, A.; Salzer, H.J.F.; Sawyer, R.; Simukulwa, N.F.; Skrahina, A.; Sriruttan, C.; Setianingrum, F.; Wilopo, B.A.P.; Cole, D.C.; Getahun, H. Case Definition of Chronic Pulmonary Aspergillosis in Resource-Limited Settings: Catalysing Research and Clinical Care. Emerg. Infect. Dis. , 2018, 24, e1-13.

16. Smith, N.L.; Denning, D.W. Underlying Conditions in Chronic Pulmonary Aspergillosis Including Simple Aspergilloma. Eur. Respir. J., 2011, 37, 865-872.

17. Kosmidis, C.; Denning, D.W. The Clinical Spectrum of Pulmonary Aspergillosis. Thorax, 2015, 70, 270-277.

18. Denning, D.W.; Riniotis, K.; Dobrashian, R.; Sambatakou, H. Chronic Cavitary and Fibrosing Pulmonary and Pleural Aspergillosis: Case Series, Proposed Nomenclature Change, and Review. Clin. Infect. Dis., 2003, 37, S265-80.

19. Jhun, B.W.; Jung, W.J.; Hwang, N.Y.; Park, H.Y.; Jeon, K.; Kang, E.S.; Koh, W.J. Risk Factors for the Development of Chronic Pulmonary Aspergillosis in Patients with Nontuberculous Mycobacterial Lung Disease. PLoS One, 2017, 12, 1-11.

20. Baker, J.; Setianingrum, F.; Wahyuningsih, R.; Denning, D.W. Mapping Histoplasmosis in South East Asia - Implications for Diagnosis in AIDS. Emerg. Microbes Infect., 2019, 8, 1139-1145.

21. Tashiro, T.; Izumikawa, K.; Tashiro, M.; Morinaga, Y.; Nakamura, S.; Imamura, Y.; Miyazaki, T.; Kakeya, H.; Yamamoto, Y.; Yanagihara, K.; Hayashi, T.; Nagayasu, T.; Kohno, S. A Case Series of Chronic Necrotizing Pulmonary Aspergillosis and a New Proposal. Jpn. J. Infect. Dis., 2013, 66, 312-316.

22. Informatian and data center Ministry of Health Republic of Indonesia. Tuberkulosis; 
medRxiv preprint doi: https://doi.org/10.1101/2021.04.25.21256062; this version posted April 27, 2021. The copyright holder for this preprint

(which was not certified by peer review) is the author/funder, who has granted medRxiv a license to display the preprint in perpetuity. It is made available under a CC-BY-NC-ND 4.0 International license .

Jakarta, 2015.

23. Al-Shair, K.; Atherton, G.T.W.; Kennedy, D.; Powell, G.; Denning, D.W.; Caress, A. Validity and Reliability of the St. George's Respiratory Questionnaire in Assessing Health Status in Patients with Chronic Pulmonary Aspergillosis. Chest, 2013, 144, 623-631.

24. Al-shair, K.; Atherton, G.T.; Harris, C.; Ratcliffe, L.; Newton, P.J.; Denning, D.W. Long-Term Antifungal Treatment Improves Health Status in Patients With Chronic Pulmonary Aspergillosis?]: A Longitudinal Analysis. 2013, 57, 828-835.

25. Bongomin, F.; Harris, C.; Hayes, G.; Kosmidis, C.; Denning, D.W. Twelve-Month Clinical Outcomes of 206 Patients with Chronic Pulmonary Aspergillosis. PLoS One, 2018, 13, 117.

26. Setianingrum, F.; Rozaliyani, A.; Syam, R.; Adawiyah, R.; Tugiran, M.; Sari, C.Y.I.; Burhan, E.; Wahyuningsih, R.; Rauteema-Richradson, R.; Denning, D.W. Evaluation and Comparison of Automated and Manual ELISA for Diagnosis of Chronic Pulmonary Aspergillosis (CPA) in Indonesia. Diagnostic Microbiol. Infect. Dis., 2020, 98, 1-6.

27. Iqbal, N.; Irfan, M.; Bin, A.; Zubairi, S.; Jabeen, K.; Awan, S.; Khan, J.A. Clinical Manifestations and Outcomes of Pulmonary Aspergillosis?: Experience from Pakistan. BMJ Open Respir. Res., 2016, 3, 1-7.

28. Singh, U.P.; Aneja, P.; Patel, A.; Patel, K. Co-Existence of HIV , Active Tuberculosis and Aspergilloma in a Single Individual - A Case Report. Indian J. Tuberc., 2013, 60, 55-58.

29. Boghani, A.; Patel, M.; Leuva, A.; Patel, B.; Patel, N.; Patel, T. Aspergilloma with Active Pulmonary Tuberculosis. Ind J Tub, 1987, 34, 206-207.

30. Ohara, S.; Tazawa, Y.; Tanai, C.; Tanaka, Y.; Noda, H.; Horiuchi, H.; Usui, K. Clinical Characteristics of Patients with Aspergillus Species Isolation from Respiratory Samples?: Comparison of Chronic Pulmonary Aspergillosis and Colonization. Respir. Investig., 2016, 54, 92-97.

31. Kwizera, R.; Parkes-Ratanshi, R.; Page, I.D.; Sekaggya-Wiltshire, C.; Musaazi, J.; Fehr, J.; Castelnuovo, B.; Kambugu, A.; Denning, D.W. Elevated Aspergillus-Specific Antibody Levels among HIV Infected Ugandans with Pulmonary Tuberculosis. BMC Pulm. Med., 2017, 17, 149.

32. Al-shair, K.; Muldoon, E.G.; Morris, J.; Atherton, G.T.; Kosmidis, C.; Denning, D.W. Characterisation of Fatigue and Its Substantial Impact on Health Status in a Large Cohort of Patients with Chronic Pulmonary Aspergillosis. Respir. Med., 2016, 114, 117-122.

33. Pasipanodya, J.G.; McNabb, S.J.; Hilsenrath, P.; Bae, S.; Lykens, K.; Vecino, E.; Munguia, G.; Miller, T.L.; Drewyer, G.; Weis, S.E. Pulmonary Impairment after Tuberculosis and Its Contribution to TB Burden. BMC Public Health, 2010, 10, 259.

34. Ralph, A.P.; Kenangalem, E.; Waramori, G.; Pontororing, G.J.; Sandjaja; Tjitra, E.; Maguire, G.P.; Kelly, P.M.; Anstey, N.M. High Morbidity during Treatment and Residual Pulmonary Disability in Pulmonary Tuberculosis: Under-Recognised Phenomena. PLoS One, 2013, 8, 1-11. 
medRxiv preprint doi: https://doi.org/10.1101/2021.04.25.21256062; this version posted April 27, 2021. The copyright holder for this preprint

(which was not certified by peer review) is the author/funder, who has granted medRxiv a license to display the preprint in perpetuity. It is made available under a CC-BY-NC-ND 4.0 International license .

35. Deve, F. Une Nouvelle Forme Anotomo-Radiologique de Mycose Pulmonaire Primitive. Arch Med Chir Appl Resp, 1938, 13, 337-361.

36. Weens, H.S.; Thompson, E. The Pulmonary Air Meniscus. Radiology, 1950, 54, 701-705.

37. Roberts, M.C.; Citron, K.M.; Strickland, B. Thoracic Intrathoracic Aspergilloma?: Role of CT in Diagnosis and Treatment. Thorac. Radiol., 1987, 165, 123-128.

38. Hamilton, C.D.; Stout, J.E.; Goodman, P.C.; Mosher, A.; Menzies, R.; Schluger, N.W.; Khan, A.; Johnson, J.L.; Vernon, A.N.; Consortium, T. The Value of End-of-Treatment Chest Radiograph in Predicting Pulmonary Tuberculosis Relapse. Int J Tuberc Lung Dis, 2008, 12, 1059-1064.

39. Zaspel, U.; Denning, D.W.; Lemke, A.J.; Greene, R.; Schurmann, D.; Maschmeyer, G.; Ruhnke, M.; Herbrecht, R.; Ribaud, P.; Lortholary, O.; Zonderland, H.; Rabe, K.F.; Bittner, R.; Oestmann, J.W. Diagnosis of IPA in HIV?]: The Role of the Chest X-Ray and Radiologist. Eur Radiol, 2004, 14, 2030-2037.

40. Clancy, C.J.; Nguyen, M.H. Acute Community-Acquired Pneumonia Due to Aspergillus in Presumably Immunocompetent Hosts .Pdf.

41. Kennedy, W.P.; Malone, D.N.; Blyth, W. Necrotizing Pulmonary Aspergillosis. Thorax, 1970, 25, 691-701.

42. Batard, E.; Renaudin, K.; Morin, O.; Desjars, P.; Germaud, P. Fatal Acute Granulomatous Pulmonary Aspergillosis in a Healthy Subject after Inhalation of Vegetal Dust. Eur. J. Clin. Microbiol. Infect. Dis., 2003, 22, 357-359.

43. Cavling Arendrup, M.; Ronan O’Driscoll, B.; Petersen, E.; Denning, D.W. Acute Pulmonary Aspergillosis in Immunocompetent Subjects after Exposure to Bark Chippings. Scand. J. Infect. Dis., 2006, 38, 945-949. 
medRxiv preprint doi: https://doi.org/10.1101/2021.04.25.21256062; this version posted April 27, 2021. The copyright holder for this preprint (which was not certified by peer review) is the author/funder, who has granted medRxiv a license to display the preprint in perpetuity. It is made available under a CC-BY-NC-ND 4.0 International license .

Table 1. Patients' characteristics at baseline assessment

\begin{tabular}{|c|c|c|c|c|}
\hline Variables & $\begin{array}{c}\text { ALL } \\
(n=216)\end{array}$ & $\begin{array}{c}\text { CPA } \\
(n=12)\end{array}$ & $\begin{array}{c}\text { non CPA } \\
(n=204)\end{array}$ & p-value \\
\hline \multicolumn{5}{|l|}{ Gender } \\
\hline Male & $102(47 \%)$ & $9(75 \%)$ & $93(46 \%)$ & \\
\hline Female & $114(53)$ & $3(25 \%)$ & $111(54 \%)$ & 0.047 \\
\hline Age (mean with range) & $39.8(17-78)$ & $44.4(23-77)$ & $39.5(17-78)$ & 0.300 \\
\hline \multicolumn{5}{|l|}{ Symptoms ( $\geq 3$ months) } \\
\hline Cough & $38(18 \%)$ & $11(93 \%)$ & $27(13 \%)$ & $<0.001$ \\
\hline Fatigue & $22(10 \%)$ & $5(42 \%)$ & $17(8 \%)$ & 0.003 \\
\hline Dyspnoea & $18(8 \%)$ & $2(17 \%)$ & $16(8 \%)$ & 0.263 \\
\hline Chest pain & $18(8 \%)$ & $3(25 \%)$ & $15(7 \%)$ & 0.067 \\
\hline Weight-loss & $4(2 \%)$ & $2(17 \%)$ & $2(1 \%)$ & 0.016 \\
\hline Haemoptysis & $2(1 \%)$ & $1(8 \%)$ & $1(1 \%)$ & 0.108 \\
\hline \multicolumn{5}{|l|}{ Intermittent } \\
\hline haemoptysis & $47(22 \%)$ & $5(42 \%)$ & $42(21 \%)$ & 0.140 \\
\hline \multicolumn{5}{|l|}{ (<3 months) } \\
\hline \multicolumn{5}{|l|}{ Radiology } \\
\hline Infiltrates & $184(85 \%)$ & $7(58 \%)$ & $177(87 \%)$ & 0.019 \\
\hline Cavitation & $117(54 \%)$ & $11(92 \%)$ & $106(52 \%)$ & 0.007 \\
\hline $\begin{array}{l}\text { Air fluid level in } \\
\text { cavities }\end{array}$ & $50(23 \%)$ & $6(50 \%)$ & $44(22 \%)$ & 0.034 \\
\hline Paracavitary fibrosis & $65(30 \%)$ & $6(50 \%)$ & $59(29 \%)$ & 0.191 \\
\hline Pleural thickening & $65(30 \%)$ & $10(84 \%)$ & $55(27 \%)$ & $<0.001$ \\
\hline Nodules & $32(15 \%)$ & 0 & $32(16 \%)$ & 0.221 \\
\hline Bronchiectasis & $31(14 \%)$ & $3(25 \%)$ & $28(14 \%)$ & 0.386 \\
\hline Aspergilloma* & $6(3 \%)$ & 0 & $6(3 \%)$ & 1 \\
\hline \multicolumn{5}{|l|}{ Chronic diseases } \\
\hline Diabetes mellitus & $38(18 \%)$ & $5(42 \%)$ & $33(16 \%)$ & 0.040 \\
\hline Hypertension & $20(9 \%)$ & $1(8 \%)$ & $19(9 \%)$ & 1.000 \\
\hline Asthma & $13(6 \%)$ & $1(8 \%)$ & $12(6 \%)$ & 0.535 \\
\hline COPD & $5(2 \%)$ & 0 & $5(3 \%)$ & 1.000 \\
\hline Chronic kidney disease & $4(2 \%)$ & 0 & $4(2 \%)$ & 1.000 \\
\hline
\end{tabular}

* One aspergilloma in non CPA group was confirmed on CT scan, the other five were unconfirmed aspergilloma diagnosed on chest-x ray. COPD: chronic obstructive pulmonary disease. 
medRxiv preprint doi: https://doi.org/10.1101/2021.04.25.21256062; this version posted April 27, 2021. The copyright holder for this preprint (which was not certified by peer review) is the author/funder, who has granted medRxiv a license to display the preprint in perpetuity.

It is made available under a CC-BY-NC-ND 4.0 International license .

Table 2. IgG tests and SGRQ results at baseline

\begin{tabular}{lcccc}
\hline \multicolumn{1}{c}{ Variables } & $\begin{array}{c}\text { ALL } \\
(\mathbf{n}=\mathbf{2 1 6})\end{array}$ & $\begin{array}{c}\text { CPA } \\
(\mathbf{n = 1 2})\end{array}$ & $\begin{array}{c}\text { non CPA } \\
(\mathbf{n = 2 0 4})\end{array}$ & p-value \\
\hline $\begin{array}{l}\text { Serology tests } \\
\text { Aspergillus IgG } \\
\text { (mg/L) }\end{array}$ & 8.7 & 15.4 & 8.3 & \\
& $(6.2-12.3)$ & $(12.4-25.3)$ & $(6.1-11.5)$ & $<0.001$ \\
SGRQ scores & & & & \\
Symptoms & 40.3 & 58 & 39 & 0.029 \\
& $(24.6-57)$ & $(38.3-69.6)$ & $(24.4-56.3)$ & \\
Impact & 40.6 & 45.8 & 39.6 & 0.549 \\
& $(21.7-53.7)$ & $(32.3-52.2)$ & $(21.2-53.9)$ & \\
Activity & 34.1 & 40 & 34.1 & 0.944 \\
& $(0-67.7)$ & $(5-64)$ & $(0-67.7)$ & \\
Total & 39.5 & 45.7 & 39 & 0.492 \\
& $(20.6-55)$ & $(29.3-54.3)$ & $(20.4-55)$ & \\
\hline
\end{tabular}

Data are given as median (interquartile range). 
Table 3. Results for end of TB therapy assessment compared to baseline for all those assessed at both time points, using the CPA categorization at the second time point

\begin{tabular}{|c|c|c|c|c|c|c|}
\hline Symptoms & $\begin{array}{l}\text { Early TB } \\
\text { therapy } \\
(n=128)\end{array}$ & $\begin{array}{l}\text { End of } \\
\text { therapy } \\
(n=128)\end{array}$ & p-value & $\begin{array}{l}\text { CPA* } \\
(n=10)\end{array}$ & $\begin{array}{l}\text { non CPA } \\
(n=118)\end{array}$ & $\begin{array}{l}\mathrm{p}- \\
\text { value }\end{array}$ \\
\hline \multicolumn{7}{|l|}{ Gender } \\
\hline Male & $52(41 \%)$ & 52 (41\%) & & $5(50 \%)$ & 47 (40\%) & \\
\hline Female & 76 (59\%) & 76 (59\%) & - & $5(50 \%)$ & $71(60 \%)$ & 0.526 \\
\hline $\begin{array}{l}\text { Age } \\
\text { (mean; range) }\end{array}$ & $\begin{array}{l}38.3(17- \\
77)\end{array}$ & $\begin{array}{l}38.3(17- \\
77)\end{array}$ & - & $\begin{array}{l}52(22- \\
77)\end{array}$ & $37.1(17-72)$ & 0.004 \\
\hline
\end{tabular}

\section{Symptoms}

( $\geq 3$ months)

$\begin{array}{lllllll}\text { Cough } & 22(17 \%) & 18(14 \%) & 0.556 & 5(50 \%) & 13(11 \%) & 0.005 \\ \text { Fatigue } & 9(7 \%) & 21(17 \%) & 0.031 & 6(60 \%) & 15(13 \%) & 0.001 \\ \text { Dyspnea } & 7(6 \%) & 16(13 \%) & 0.064 & 3(30 \%) & 13(11 \%) & 0.111 \\ \text { Chest pain } & 6(5 \%) & 7(6 \%) & 1 & 2(20 \%) & 5(4 \%) & 0.094 \\ \text { Weightloss } & 5(4 \%) & 3(2 \%) & 0.727 & 0 & 3(3 \%) & 1.000 \\ \text { Haemoptysis } & 3(2 \%) & 3(2 \%) & 0.727 & 1(10 \%) & 2(2 \%) & 0.218 \\ \text { Intermittent } & & & & & & \\ \text { haemoptysis } & 24(19 \%) & 3(2 \%) & <0.001 & 1(14 \%) & 2(3 \%) & 0.286 \\ \text { (<3 months) } & & & & & & \\ \text { Radiology } & & & & & & \\ \text { Infiltrates } & 123(96 \%) & 102(80 \%) & <0.001 & 8(80 \%) & 94(80 \%) & 1.000 \\ \text { Cavitation } & 67(52 \%) & 45(35 \%) & <0.001 & 7(70 \%) & 38(32 \%) & 0.033 \\ \text { Paracavitary } & 43(34 \%) & 28(22 \%) & 0.001 & 4(40 \%) & 24(20 \%) & 0.224\end{array}$


medRxiv preprint doi: https://doi.org/10.1101/2021.04.25.21256062; this version posted April 27, 2021. The copyright holder for this preprint (which was not certified by peer review) is the author/funder, who has granted medRxiv a license to display the preprint in perpetuity. It is made available under a CC-BY-NC-ND 4.0 International license.

Fibrosis

Pleural

thickening

$$
32(25 \%)
$$

$31(24 \%)$

1

$5(50 \%) \quad 26(22 \%)$

0.061

Nodules

$23(18 \%)$

$15(12 \%)$

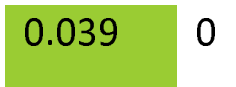

$15(13 \%)$

0.605

Air fluid level

in cavities

$21(16 \%) \quad 4(3 \%)$

$<0.001$

$1(10 \%)$

$3(3 \%)$

0.281

Aspergilloma**

$3(2 \%)$

$4(3 \%)$

1

$1(10 \%)$

$3(3 \%)$

0.281

Bronchiectasis

$8(6 \%)$

$13(10 \%)$

$0.125 \quad 1(10 \%)$

$12(10 \%)$

1.000

* Proven CPA

** One aspergilloma in baseline (non CPA) was confirmed on CT scan, the rest were unconfirmed aspergilloma diagnosed on chest-x ray. 
medRxiv preprint doi: https://doi.org/10.1101/2021.04.25.21256062; this version posted April 27, 2021. The copyright holder for this preprint (which was not certified by peer review) is the author/funder, who has granted medRxiv a license to display the preprint in perpetuity.

It is made available under a CC-BY-NC-ND 4.0 International license .

Table 4. IgG tests and SGRQ comparisons for all patients assessed at baseline and at end of TB therapy, using the CPA categorization at the second time point

\begin{tabular}{|c|c|c|c|c|c|c|}
\hline Variables & $\begin{array}{l}\text { Early TB } \\
\text { therapy } \\
(n=128)\end{array}$ & $\begin{array}{l}\text { End of } \\
\text { therapy } \\
(n=128)\end{array}$ & $\begin{array}{l}p- \\
\text { value }\end{array}$ & $\begin{array}{l}\text { CPA } \\
(n=10)\end{array}$ & $\begin{array}{l}\text { non CPA } \\
(n=118)\end{array}$ & $\begin{array}{l}\mathrm{p}- \\
\text { value }\end{array}$ \\
\hline
\end{tabular}

\section{Serology tests}

Aspergillus-

specific IgG

9.2

(6.5-12.7)

9.7

(6.9-14.2)

24.2

0.078

$(13.8-76.1)$

9

$(\mathrm{mg} / \mathrm{L})$

\section{SGRQ scores}

\begin{tabular}{|c|c|c|c|c|c|c|}
\hline Symptoms & $\begin{array}{l}37.2 \\
(18.4-56.7)\end{array}$ & $\begin{array}{l}3 \\
(0-22.5)\end{array}$ & $<0.001$ & $\begin{array}{l}23.3 \\
(9.6-37.3)\end{array}$ & $\begin{array}{l}3 \\
(0-21.1)\end{array}$ & 0.002 \\
\hline Impact & $\begin{array}{l}39 \\
(21.5-51.9)\end{array}$ & $\begin{array}{l}4 \\
(0-13.6)\end{array}$ & $<0.001$ & $\begin{array}{l}9.2 \\
(5-37.7)\end{array}$ & $\begin{array}{l}3.7 \\
(0-13.1)\end{array}$ & 0.007 \\
\hline Activity & $\begin{array}{l}21.9 \\
(0-59.4)\end{array}$ & $\begin{array}{l}0 \\
(0-8.4)\end{array}$ & $<0.001$ & $\begin{array}{l}23.6 \\
(0-53.9)\end{array}$ & $\begin{array}{l}0 \\
(0-0)\end{array}$ & 0.002 \\
\hline Total & $\begin{array}{l}35.9 \\
(16.3-51.4)\end{array}$ & $\begin{array}{l}4.8 \\
(4-12.8)\end{array}$ & $<0.001$ & $\begin{array}{l}17.4 \\
(8-36.8)\end{array}$ & $\begin{array}{l}3.4 \\
(0-12.2)\end{array}$ & 0.003 \\
\hline
\end{tabular}

Data are given as median (interquartile range). 


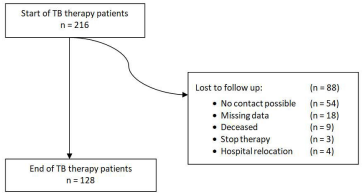

Figure 1 Overview of the study population 


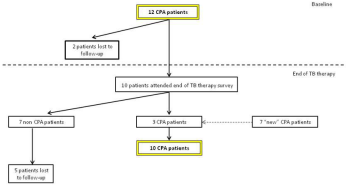

Figure $\mathbf{2}$ Chronic pulmonary aspergillosis patients during two time-point assessments 